\title{
Risk Management Practices and Firm Performance with a Mediating Role of Business Model Innovation. Observations from Jordan
}

\author{
Munther Al-Nimer ${ }^{1}$, Sinan S. Abbadi ${ }^{2}$, Ahmad Al-Omush ${ }^{1}$ and Habib Ahmad ${ }^{3, *}$ \\ 1 Administrative Science Accounting Department, Faculty of Economics, The Hashemite University, \\ P.O. Box 330127, Zarqa 13133, Jordan; Muntheralnimer@hu.edu.jo (M.A.-N.); \\ Ahmad.omush@hu.edu.jo (A.A.-O.) \\ 2 Accounting Department, Faculty of Business, Balqa' Applied University, Al-Salt 19117, Jordan; \\ sinan@bau.edu.jo \\ 3 Air University School of Management (AUSOM), Islamabad 44000, Pakistan \\ * Correspondence: habib.ahmad@students.au.edu.pk
}

\section{check for} updates

Citation: Al-Nimer, Munther, Sinan S. Abbadi, Ahmad Al-Omush, and Habib Ahmad. 2021. Risk

Management Practices and Firm

Performance with a Mediating Role of Business Model Innovation. Observations from Jordan. Journal of Risk and Financial Management 14: 113 https://doi.org/10.3390/jrfm14030113

Academic Editors: Shigeyuki Hamori and Sorin Gabriel Anton

Received: 30 January 2021

Accepted: 26 February 2021

Published: 9 March 2021

Publisher's Note: MDPI stays neutral with regard to jurisdictional claims in published maps and institutional affiliations.

Copyright: (c) 2021 by the authors. Licensee MDPI, Basel, Switzerland. This article is an open access article distributed under the terms and conditions of the Creative Commons Attribution (CC BY) license (https:/ / creativecommons.org/licenses/by/ $4.0 /)$.

\begin{abstract}
This study focused on scrutinizing the influence of Enterprises Risk Management (ERM) on firm performance with a mediating role of Business Model Innovation (BMI). For the purpose, data from 228 Jordanian firms was collected and analyzed. The results indicated that the ERM practices have a significant influence on BMI and financial firm's performance. The BMI significantly contributed to the financial and nonfinancial performance, whereas it displayed insignificant effects regarding environmental performance. The BMI fully mediated the relationship between ERM practices and financial performance, where a partial mediating effect was observed for the path between ERM practices and nonfinancial performance, while showed no mediating role between the ERM practices and environmental performance. Economies of countries like Jordan are hereby urged to implement the formal ERM practices and to financially educate their top management teams to apply the BMI to gain first-rate performance. This study also encourages the researchers from other countries to extend this model to their economies to unleash useful insights.
\end{abstract}

Keywords: enterprise risk management practices; Business Model Innovation; financial performance; financial sector; emerging markets

\section{Introduction}

The business organizations used to apply traditional tactics to performance for the purpose of maximizing profitability, values and sales. However, the business organizations have now realized the importance of environmental and nonfinancial performance because of the community pressure and governmental regulations (Ilyas et al. 2020; Memon et al. 2020). Consequently, several strategies have been introduced to gain desirable environmental, financial and nonfinancial performance namely modern technology (Chege and Wang 2020; Singh et al. 2019), financial resources (Khattak 2020; Memon et al. 2020), intellectual capital (Demartini and Beretta 2020), entrepreneurial orientation (Amankwah-Amoah et al. 2019), knowledge management (Kmieciak and Michna 2018; Roxas and Chadee 2016) and enterprise risk management (ERM) (Brustbauer 2016; Shad et al. 2019), all of which are found to be relevant and equally important but the ERM in particular has become a key predictor of performance in financial institutions because they are persistently engaged in the reduction of financial loss and risk (Rasid et al. 2014). As an emphasis, after the 2007-2008 financial crises, most banks and financial institutions established a formal ERM framework to mitigate potential risk (Adedayo et al. 2019). The ERM department focuses on the new and emerging ways of risk reduction (Hopper 2019). Additionally, it is legally required by the US firms to have a formal ERM framework to avoid risk and loss (Whitman 2015). With reference to Jordanian financial institutions, ERM 
is very important for profitability and performance but little attention has been given to it so far. For instance, a study conducted by Chen et al. (2020) in Taiwan financial industry concluded that the implementation of ERM significantly improved the cost effectiveness by $9.22 \%$ and revenues by $16.34 \%$ of the financial industry. Despite having an extensive number of studies, what is not yet known is whether ERM directly or indirectly contributes to the performance of financial institutions via Business Model Innovation (BMI). It has been found that an enterprise with effective BMI enjoys desirable performance in a turbulent market (Anwar 2018). However, the role of BMI in the environmental, financial and nonfinancial performance of financial institutions has received negligible attention. Additionally, studies have shown that the BMI does not come directly but require business capabilities, strategies and resources (Anwar and Shah 2020). Firms need corporate entrepreneurship (Karimi and Walter 2016), entrepreneurial behaviors (Futterer et al. 2018) and entrepreneurial orientation (Asemokha et al. 2019) to enjoy an effective BMI. However, it is still in question as to how the ERM practices enable firms to build their BMI. Although Hock-Doepgen et al. (2020) claimed that the BMI needs risk-taking behaviors by firms, how the ERM practices actually influence the BMI still remains as an unanswered question in the literature. Moreover, it has also been reported that the BMI works as a suitable mediator between an enterprise's strategies, capabilities, resources and performance (Guo et al. 2017; Najmaei 2016) but the mediating role of BMI between ERM and performance still remain unexplored.

The detrimental reasons for examining the mediating role of BMI in this study includes that the previous studies have presented fragmented results (negative, positive and no relationship) between ERM and performance (Di Gravio et al. 2013; Lin et al. 2012; Rehman and Anwar 2019), while some studies have claimed that ERM practices do not directly improve firm performance and that other determinants mediate and moderate the paths (Wijethilake and Lama 2019; Wu and Wu 2014; Yang et al. 2018). Moreover, worldwide financial institutions and banks face a big threat of loss and risk. Our research may assist them in understanding the role of ERM in creating a good and effective business model that will spur their performance. The financial crises of 2007-2008 have compelled the firms towards adopting the ERM framework. However, we claim that the current crisis, e.g., COVID 19 pushes firms to establish an effective BMI to gain high performance and effectively respond to the crisis. Therefore, the enabling role of BMI is worthy of investigation for determining the relation between the ERM and the performance of financial institutions. Additionally, the present study has several implications for practicing managers of financial institutions and the banking sector operating in Jordan as well as across the globe. It will enable the financial firms to build a useful BMI through the promotion of ERM practices. This research will also facilitate the banking sector regarding the unknown benefits (environmental performance, nonfinancial performance and BMI) of ERM practices. Most of the financial firms in emerging economies invest their money in useful strategies, such as ERM and BMI, rather than in projects with a high risk of failure and loss. This research will also help top managers of financial firms to reconfigure their strategic position and processes by scoping the environmental and nonfinancial activities through ERM and BMI and will be able to occupy a sustainable position in the market that can yield long-term benefits.

This research advances our understanding concerning the Resource-Based View (RBV) theory which sheds light on the value of tangible and intangible resources for superior performance (Barney 1991). The theory has been rarely touched in the context of ERM and organizational performance (Rehman and Anwar 2019; Anwar 2018). In the present study, we assessed whether the intangible resource, namely ERM, contributes to firm performance through BMI or not. Although this theory has been tested in other domains of research, it has not yet been discussed in the context of ERM, BMI and the performance of financial institutions. 


\subsection{Conceptual Background}

\subsubsection{Financial Industry, Jordan}

This study focuses on Jordan's financial sector, which comprises banks, insurance companies, financial intermediaries, financial services companies, exchange companies, microfinance institutions, leasing companies, mixed financing companies and financing companies. The financial sector in Jordan is dominated by banks, which account for $93.5 \%$ of the sector's assets, totaling to JD 49.1 billion by the end of 2019. Following banks, the insurance sector is considered the most important among all economic sectors because it provides appropriate coverage for any economic process and acts as a security shield for the financial sector. The gross insurance premium's percentage of GDP by current prices for 2016 was reported to be $2.12 \%$ for 2016 and 2.09\% for 2017 (Khresiat 2019). These financial institutions provide financial services, loans and leasing assets to the customers and engaged in the reduction of potential losses.

\subsubsection{ERM Practices}

COSO (2004, p. 12) defines the ERM as "a process, effected by an entity's board of directors, management and other personnel, applied in strategy setting and across the enterprise, designed to identify potential events that may affect the entity, and manage risk to be within its risk appetite, to provide reasonable assurance regarding the achievement of the entity objectives". Besides, the ERM was introduced as an instrument that can enhance corporate governance practices, primarily through risk management (Maruhun et al. 2018). There are several types of risk groups, namely the investment risk, the business risk, the financial risks and the nonfinancial risks. In financial institutions, risk includes credit risk, market risk and operational risk (Hendriks 2013; Jonek-Kowalska 2019; Soltanizadeh et al. 2016).

According to Lobo et al. (2019), a high degree of risk disclosure intensity contains both mandatory and voluntary risk management disclosures. Recently, it has been debated whether to move the organizations toward strategic risk management, which would result in separate considerations of operational and strategic risk or not (Pierce and Goldstein 2018). An effective ERM significantly affects the firm performance (Malik et al. 2020). Moreover, the ERM tools can be utilized to evaluate the performance indicators for public and private firms (Ivanyos and Sándor-Kriszt 2016). ERM has a significant effect on competitive advantage and IT strategy where the IT structure have a significant impact on competitive advantage, thereby constituting a moderating effect on the association between ERM and competitive advantage (Saeidi et al. 2019).

\subsubsection{Business Model Innovation}

In recent years, there has been a significant increase in academic attention to BMI (Spieth et al. 2014). The BMI can be defined as "the discovery of a fundamentally different business model in an existing business" (Markides 2006, p. 20), or as "the search for new business logics of the firm and new ways to create and capture value for its stakeholders" (Casadesus-Masanell and Zhu 2013, p. 464). In addition, academic conferences and management workshops on business models and BMI have similarly experienced market growth in the demand to participate. Nevertheless, BMI is still characterized as "a slippery construct to study" (Casadesus-Masanell and Zhu 2013, p. 480). Running the business involves adjusting and understanding the operational roles assigned to business models by addressing operational aspects such as processes, linkages or structures (Velu and Stiles 2013; Zott and Amit 2008). Finally, developing the business is associated with the strategic function of the business model. In this regard, a business model's function is to support management in defining and developing the business's strategy (Casadesus-Masanell and Zhu 2013; Markides 2013). BMI has an impact on new firms that makes them more likely to survive for longer (Anwar 2018; Velu 2015). According to Geissdoerfer et al. (2018), BMI is a key for financial performance and sustainability. 


\section{Literature Review Hypothesis Development}

\subsection{ERM and Firm Performance}

The financial industry has opted for ERM practices for the reduction of costs, risk and potential loss (Adam et al. 2021; Mustafa and Al-Nimer 2018). Several studies have found that the ERM has a significant effect on the financial performance of companies (Shad and Lai 2019; Liem 2018; Olayinka et al. 2017; Soliman and Adam 2017). Another approach has focused on operational performance and ERM (Altanashat et al. 2019; Callahan and Soileau 2017; Panić et al. 2019). According to Dey et al. (2018), there is a significant association between the degree of financial risk disclosure and a firm's financial characteristics as a function of firm size, financial performance and auditor. Soliman and Adam (2017) indicated that there is a significant association between ERM implementation and financial performance indicators in banking sector. According to Yang et al. (2018), the ERM significantly influences competitive advantage and firms' performance. Dey et al. (2018) found a significant association between the degree of financial risk disclosure and a firm's financial performance. Lately, Malik et al. (2020) revealed the effectiveness of ERM with significant impact on the firm performance. According to Rehman and Anwar (2019), ERM practices work as an intangible resource that significantly improves firms' performance.

Olayinka et al. (2017) similarly found that the ERM has a significant impact on the financial performance of listed firms in the financial sector. A study carried out by Rasid et al. (2017) indicated that the ERM adoption significantly influences organizational performance. Besides, Altanashat et al. (2019) indicated that ERM disclosure has a significant effect on improving the performance of companies. Liem (2018) showed that ERM has a positive and significant influence on banks' profitability, which will be a useful indicator for the shareholders. A recent study by Kashif Shad and Lai (2019) revealed that four components, i.e., supportive internal environment, objective setting, control and monitoring activities of the ERM framework have a significant and positive effect on a firm's performance. Recently, Malik et al. (2020) demonstrated that the ERM significantly affects an organization's performance. Besides, their study also found that a board-level risk committee, as a vital governance mechanism, has a significant impact on increasing the organizational performance effects of ERM. Therefore, the following hypotheses are proposed:

Hypothesis 1 (H1). ERM practices are significantly influencing organizational financial performance.

Hypothesis 2 (H2). ERM practices are significantly influencing organizational nonfinancial performance.

Hypothesis 3 (H3). ERM practices are significantly influencing organizational environmental performance.

\subsection{ERM and BMI}

ERM in the context of BMI is considered to be an unexplored area (Taran et al. 2013) as there have been limited studies carried out to develop a more profound understanding of how and when risk management can be incorporated into a company's BMI process (Kalvet and Lember 2010; Maruhun et al. 2018). The business risk management model leads managers to focus on identifying problematic issues and putting clear plans and schedules into place for resolving or reducing risks, and it helps companies to align the risk behavior choices made through the innovation process with the company's corporate strategy and risk appetite. Besides, the implementation of risk management through the innovation process decreases the risks linked to the uncertainty and density of developing and implementing a new business model (Taran et al. 2013). Therefore, there is a benefit to implement risk management practices in a strategic performance model for innovative organizations (Etges et al. 2017). BMI needs heavy investment and has a high level of 
uncertainty, complexity, unavoidably and risk. Although many firms follow a first-mover strategic approach and maintain a "no risk no reward" status, perhaps a messy implementation of BMI might have catastrophic, even fatal consequences for a firm's fundamental business (Taran et al. 2015). Accordingly, the following hypothesis is proposed:

Hypothesis 4 (H4). ERM practices are significantly influencing business model innovation in organizations.

\subsection{BMI and Firm Performance}

Some recent studies have considered the relation between BMI and firm performance and have concluded that different types of BMI influence the firm performance, as evaluated by different measurements such as financial, operational and environmental performance (Foss and Saebi 2017; Lin et al. 2020; Morris et al. 2013). According to Anwar (2018), BMI has a significant and positive impact on competitive advantage and small firms' performance, and firms need to create an effective business model to acquire competitive advantage and superior financial performance. On other hand, the BMI with an efficiency design theme results in higher environmental performance; thus, BMI affects firm performance (Hamelink and Opdenakker 2019). Moreover, technological innovation has a positive impact on firm performance (Lin et al. 2020). Enhancing ERP implementation can lead to a higher return on the costs and revenue (improving the financial performance) associated with BMI (Rodríguez et al. 2020). Therefore, a firm's innovation performance positively influences its business performance (Rangus and Slavec 2017). BMI in cooperation with entrepreneurial orientation is an important driver of international performance for internationalizing SMEs (Asemokha et al. 2019). In addition, the effective management of innovation capability can deliver more effective innovation outcomes that will generate a better financial performance (Rajapathirana and Hui 2018). Therefore, the following hypotheses are proposed:

Hypothesis 5 (H5). BMI significantly influences organizational financial performance.

Hypothesis 6 (H6). BMI significantly influences organizational nonfinancial performance.

Hypothesis 7 (H7). BMI significantly influences environmental performance.

\subsection{Mediating Role of BMI between ERM and Performance}

ERM practices are essential to build an effective business model (Casadesus-Masanell and Zhu 2013) that alternatively adds value to the performance and profitability of firms. ERM facilitates firms in building a business model for the reduction of cost and risk which supports the profitability of firms (Chen et al. 2020). Foerstl et al. (2010) demonstrate that the ERM assist firms in the supply management process and organizing their resources in a better way for sustainability and social activities. BMI is considered a key conduit through which opportunity recognition affects SME performance, as there is a significant relationship between opportunity recognition as an ERM, and SME performance is mediated by BMI (Guo et al. 2017). We argue that BMI is a new process and organizing way that mediates the path between ERM and firm performance. In addition, BMI partially mediates between customer orientation and SME performance (Bamfo and Kraa 2019). BMI has also been suggested to mediate the relation between international R\&D sourcing strategies and sales growth as financial performance indicators (Rodríguez and Nieto 2016). Moreover, product and process innovation as BMI types mediate the relations between knowledge combination capability and organizational performance (Ruiz-Jiménez and Fuentes-Fuentes 2013). Therefore, the following hypotheses are proposed:

Hypothesis 8 (H8). The association between ERM and financial performance is mediated by BMI. 
Hypothesis 9 (H9). The association between ERM and nonfinancial performance is mediated by BMI.

Hypothesis 10 (H10). The association between ERM and environmental performance is mediated by BMI.

The hypothesized relationship and the variables are shown in Figure 1.

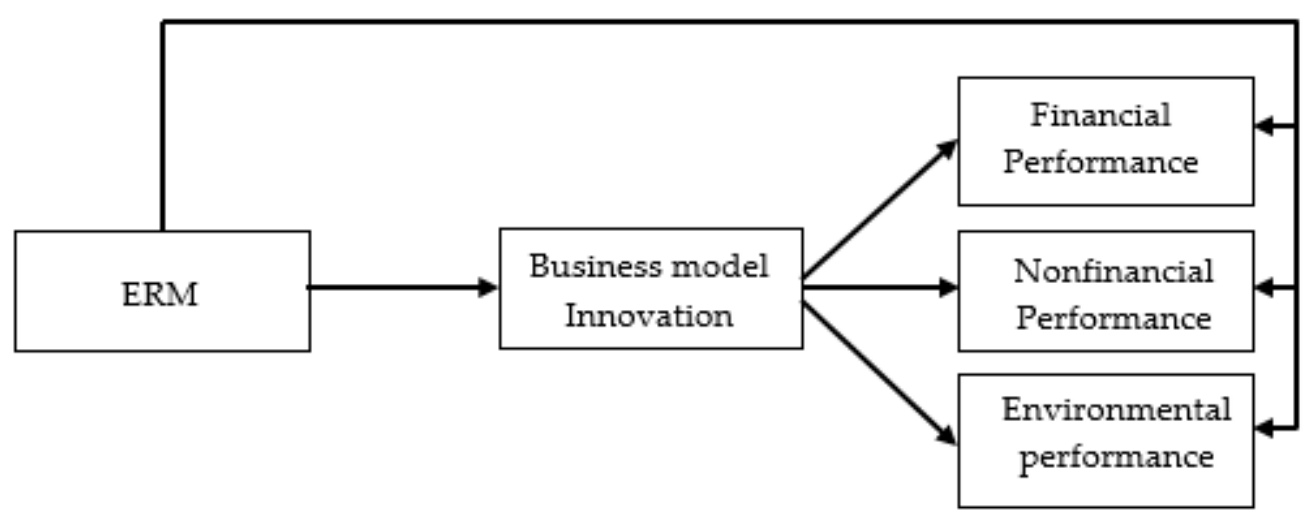

Figure 1. Research model.

\section{Methodology}

\subsection{Design, Sample and Methodology}

A quantitative methodology approach was used in this study and a deductive approach was adopted for assessing an existing theory based on the empirical evidence collected from Jordanian financial firms. We targeted financial institutions namely banks, insurance companies, financial intermediaries, financial services companies, exchange companies, microfinance institutions, leasing companies, mixed financing companies and financing companies. We used self-reported measures because many firms have not reported data on ERM. Moreover, it was difficult to measure BMI with lack of information and available data. We used a structured questionnaire to collect the data from the firms. The questionnaire was divided into two sections. In the first part, the financial institutions were asked questions regarding ERM, BMI and performance while the second part comprised of questions about the enterprise and demographic details of the senior and responsible managers. For the purpose, hard copy versions of the questionnaires were used instead of online surveys, since on one hand online surveys are time consuming and on the other hand have low response rate due to busy schedule of managers in the business industry who are responsible for the strategic planning and performance of their firms. To achieve a desirable response rate and unbiased information, it was clearly communicated to the target people that the information so obtained will only be used for research purposes and confidentiality will be upheld to the maximum. A total of 400 questionnaires were distributed among the enterprises where one firm was to complete one questionnaire preferably by the top management team and managers responsible for the business and strategic planning. The questionnaires were developed bilingually, i.e., English and in Arabic to help the target population easily understand it. Over two months period (i.e., Feb to March 2020), a total of 305 responses from the enterprises were received. Among which some questionnaires were incorrectly completed, and a few were missing the important information about the variables, hence they were excluded from the survey. The total acceptable responses thus becomes 228, representing a $57 \%$ response rate.

Details of the managers and their firms are given in Table 1. The highest number of participating firms were financial institutions, followed by financial firms (small size ventures), insurance firms and banks. Most of the firms were having 20 to 50 employees, 
and only 48 firms were having 101-250 employees. It is also clear from the sample that most of the firms had begun their operations in the past 10 years.

Table 1. Profile of the firms.

\begin{tabular}{lcc}
\hline \multicolumn{1}{c}{ Description } & No. of Firms/Managers & Percentage \\
\hline Nature of industry & 37 & \\
1. Banks & 51 & 16.2 \\
2. Insurance & 86 & 22.4 \\
3. Financial institutions & 54 & 37.7 \\
4. Financial firms & & 23.7 \\
Educational background & 18 & \\
1. FA and less & 132 & 7.9 \\
2. BA/BSc/BCom & 62 & 57.9 \\
3. MA/MBA & 16 & 27.2 \\
4. MPhil and above & & 7.0 \\
Size (Number of employees) & 95 & \\
1. 20-50 & 81 & 41.7 \\
2. 51-100 & 26 & 35.5 \\
3. 101-150 & 26 & 11.4 \\
4. 151-250 & & 11.4 \\
Age (Years since launch) & 122 & \\
1. 10 or fewer & 75 & 53.5 \\
2. 11-20 & 31 & 32.9 \\
3. 21 or more & 228 & 13.6 \\
Total & & 100 \\
\hline
\end{tabular}

\subsection{Measurement of Variables}

The variables used in this study are discussed below. We used five-point Likert scales ranging from 1 = strongly disagree to $5=$ strongly agree to measure the variables. For detail questions, please read the Appendix A.

Enterprise Risk Management: This indicates the capacity and policy of enterprises regarding the management of risk. We used six items to measure ERM that were used by Rehman and Anwar (2019) where 0.70 reliability has been traced. These items have been validated in emerging firms with satisfactory convergent validity and composite reliability. A sample item is: "We have standard procedures in place for identifying major risks and opportunities."

Business Model Innovation: BMI encompasses restructuring the existing model in a way to gain higher value (Anwar 2018). Studies have used several measures for BMI (Anwar 2018; Anwar and Shah 2020). We relied on nine items that are mostly used in the literature on firms and have been validated by Guo et al. (2013) and Anwar et al. (2019) with 0.94 and 0.92 , respectively. A sample item is: "Our business model attracts a lot of new suppliers and partners."

Environmental Performance: This describes the performance of an enterprise in terms of recycling waste, reducing air pollution, environmental protection, environmental safety, and so on (Martinez-Conesa et al. 2017). We used five items to measure the environmental performance of firms that were taken from Memon et al. (2020) with a reliability of 0.86. A sample item is: "Designs products and packaging to be reused, repaired or recycled."

Financial Performance: This refers to the performance of an organization in terms of profitability, return on equity, return on investment, return on assets and so on. In the case of listed organizations, measuring financial performance is not difficult as researchers can use secondary data and financial reports. However, due to data limitation and unavailability, measuring firms' financial performance can be difficult for researchers (Rehman and Anwar 2019; Anwar 2018). Researchers have, therefore, suggested self-reported measures whereby scholars collect information from owners/managers through a survey by asking them to "select a suitable option from 'strongly declined (1), to strongly improved (5)' of your firm's performance based on return on assets, sales growth, return on equity and 
investment, etc. in the last three years as compared to your major competitors" (Anwar and Shah 2020; Memon et al. 2020). The reliability of financial performance was found 0.88 (Memon et al. 2020).

Nonfinancial Performance: this indicates the performance of organizations in terms of reputation, customer loyalty, employee satisfaction and so on. To measure the nonfinancial performance of firms, we used four items taken from Anwar and Shah (2020) with a reliability value of 0.84 .

\section{Data Analysis}

AMOS.21 was used to test the hypotheses. However, before testing the main model, certain preliminary screening tests were executed which are listed and discussed below.

\subsection{Descriptive Statistics}

In this test, we checked mean values, standard deviation values, skewness and kurtosis of the constructs. These are presented in Table 2. Financial performance was having the highest Mean (M) value of 3.6, while nonfinancial performance with the lowest $M$ value of 2.6. However, the environmental performance was having the highest SD of 0.48 , while nonfinancial performance was having the lowest SD of 0.30 . The results of both skewness and kurtosis indicated that the data is normally distributed because the values are below the threshold \pm 2 (George 2011).

Table 2. Descriptive statistics.

\begin{tabular}{cccccc}
\hline Variables & N & Mean & Std. Deviation & Skewness & Kurtosis \\
\hline ERM & 228 & 3.1101 & 0.37282 & 0.486 & -1.498 \\
BMI & 228 & 3.3657 & 0.36547 & -0.269 & -0.730 \\
Financial Performance & 228 & 3.6221 & 0.40036 & -0.591 & -0.671 \\
Nonfinancial Performance & 228 & 2.6215 & 0.29983 & 0.274 & -1.637 \\
Environmental Performance & 228 & 3.5371 & 0.48312 & -0.377 & 0.207 \\
\hline
\end{tabular}

\subsection{Common Method Variance}

The issue of common method variance arises during a cross-sectional data set (data collected through a single source, at the same time and from a single respondent). Hence Harman's one-factor test in SPSS where all items were included was used and the analysis revealed that the collected data is free of common method variance since the five factors with $68.77 \%$ variation illustrated the first factor with $25.14 \%$ variance (Podsakoff and Organ 1986).

\subsection{Confirmatory Factor Analysis}

We executed a measurement model (see Figure 2) to ensure the validity and reliability of the constructs. A value 0.70 or above is considered as an acceptable value for standardized factor loadings (Hair et al. 2017). However, if overall items of a single constructs give an average standardized value of 0.70 and above, then an item having factor loading close to 0.70 can be retained (Hair et al. 2017). In our research, the average standardized factor loading of all the variable were satisfactory ( 0.70 or above) and all the items were significantly loaded $(p<0.001)$ on their respective construct. Additionally, we checked modification indices and acknowledged that a few items were significantly correlated that created problem in model fit. Hence, we drew a covariance between the error terms of e13 and e15, e8 and e9, e20 and e21 and e27 and e29. After running the model again, we found acceptable values of the model fits; $\chi 2 / \mathrm{df}=1.772$ which is below 3 , as per the suggestions of Ding et al. (1995). GFI $=0.84$, AGFI $=0.81$, TLI $=0.92$ and $\mathrm{NFI}=0.85$ values are in the recommended range (close to or greater than 0.90), as per the suggestion of Fan et al. (1999). RMSEA $=0.058$ and $\mathrm{RMR}=0.014$ values should be lower than 0.09 for an acceptable model fit, and our model met this condition. 


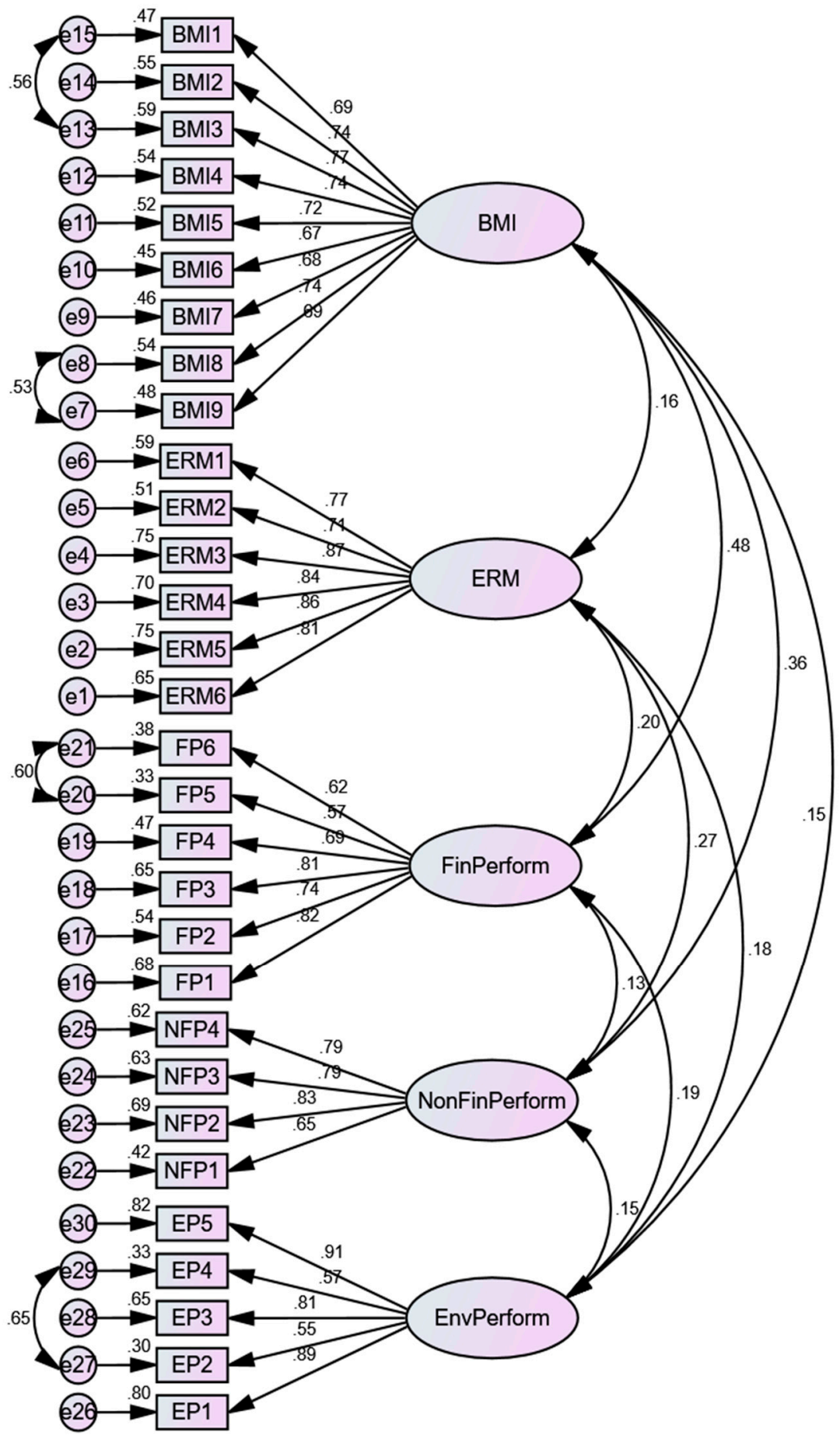

Figure 2. Measurement model.

The validity and reliability results of the study are depicted in Table 3. Convergent validity indicates the average variance explained by the items in a single construct (Garver and Mentzer 1999). If the items explain $50 \%$ or more variance, it means there is satisfactory convergent validity (Garver and Mentzer 1999). Our research met the condition because all the constructs displayed adequate values. 
Table 3. Validity and reliability.

\begin{tabular}{|c|c|c|c|c|c|}
\hline Item No & Estimate & AVE & $\sqrt{ }$ AVE & C.R. & Cronbach's Alpha \\
\hline $\begin{array}{c}\text { Enterprise Risk } \\
\text { Management }\end{array}$ & & 0.66 & 0.81 & 0.92 & 0.92 \\
\hline ERM6 & $0.81 *$ & & & & \\
\hline ERM5 & $0.86^{*}$ & & & & \\
\hline ERM4 & $0.84 *$ & & & & \\
\hline ERM3 & $0.87 *$ & & & & \\
\hline ERM2 & $0.71 *$ & & & & \\
\hline ERM1 & $0.77 *$ & & & & \\
\hline $\begin{array}{l}\text { Business Model } \\
\text { Innovation }\end{array}$ & & 0.51 & 0.72 & 0.90 & 0.91 \\
\hline BMI9 & $0.69 *$ & & & & \\
\hline BMI8 & $0.74 *$ & & & & \\
\hline BMI7 & $0.68 *$ & & & & \\
\hline BMI6 & $0.67 *$ & & & & \\
\hline BMI5 & $0.72 *$ & & & & \\
\hline BMI4 & $0.74 *$ & & & & \\
\hline BMI3 & $0.77^{*}$ & & & & \\
\hline BMI2 & $0.75 *$ & & & & \\
\hline BMI1 & $0.69 *$ & & & & \\
\hline Financial Performance & & 0.51 & 0.71 & 0.86 & 0.87 \\
\hline FP1 & $0.83 *$ & & & & \\
\hline FP2 & 0.74 * & & & & \\
\hline FP3 & $0.81 *$ & & & & \\
\hline FP4 & $0.69 *$ & & & & \\
\hline FP5 & $0.57 *$ & & & & \\
\hline FP6 & $0.62 *$ & & & & \\
\hline Nonfinancial Performance & & 0.59 & 0.77 & 0.85 & 0.85 \\
\hline NFP1 & $0.65 *$ & & & & \\
\hline NFP2 & $0.83 *$ & & & & \\
\hline NFP3 & $0.79 *$ & & & & \\
\hline NFP4 & $0.79 *$ & & & & \\
\hline $\begin{array}{l}\text { Environmental } \\
\text { Performance }\end{array}$ & & 0.58 & 0.76 & 0.87 & 0.88 \\
\hline EP1 & $0.90 *$ & & & & \\
\hline EP2 & $0.55 *$ & & & & \\
\hline EP3 & 0.81 * & & & & \\
\hline EP4 & $0.57^{*}$ & & & & \\
\hline EP5 & $0.91 *$ & & & & \\
\hline
\end{tabular}

$\mathrm{AVE}=$ Average variance extracted, $\mathrm{CR}=$ Composite reliability, ${ }^{*}$ significant at $p$ value 0.001 .

Composite reliability refers to the internal consistency of the constructs and states whether the items are reliable. A value greater than 0.70 indicates satisfactory reliability (Hair et al. 2017), and our research has met this condition.

Discriminant validity indicates whether the items explain unique variance in a particular construct. The square root of AVE shows discriminant validity, with a recommended value above 0.70 (Garver and Mentzer 1999). Our results displayed desirable values for all the constructs.

\subsection{Correlations}

The relationships between the variables are presented in Table 4 . This shows that the ERM is significantly related to BMI $(r=0.173, p<0.01)$, financial performance $(r=0.215$, $p<0.01)$, nonfinancial performance $(r=0.297, p<0.01)$ and environmental performance $(r=0.199, p<0.01)$. 
Table 4. Correlations.

\begin{tabular}{|c|c|c|c|c|c|c|c|c|}
\hline Variables & 1 & 2 & 3 & 4 & 5 & 6 & 7 & 8 \\
\hline 1. Education & 1 & & & & & & & \\
\hline 2. Size & $0.237^{* *}$ & 1 & & & & & & \\
\hline 3. Age & $0.445^{* *}$ & $0.422 * *$ & & & & & & \\
\hline 4. ERM & 0.064 & $-0.174^{* *}$ & -0.102 & $(0.81)$ & & & & \\
\hline 5. BMI & -0.063 & 0.054 & $-0.181^{* *}$ & $0.173^{* *}$ & $(0.72)$ & & & \\
\hline 6. Financial Performance & -0.085 & -0.076 & $-0.261^{* *}$ & $0.215^{* *}$ & $0.531^{* *}$ & $(0.71)$ & & \\
\hline 7. Nonfinancial Performance & -0.094 & -0.109 & -0.052 & $0.297^{* *}$ & $0.397^{* *}$ & $0.151 *$ & $(0.85)$ & \\
\hline 8. Environmental Performance & -0.024 & 0.088 & -0.064 & $0.199 * *$ & $0.167 *$ & $0.209^{* *}$ & $0.170 * *$ & $(0.87)$ \\
\hline
\end{tabular}

** Correlation is significant at the 0.01 level (2-tailed); ${ }^{*}$ Correlation is significant at the 0.05 level (2-tailed). The values in bracket and parallel to correlation are discriminant validity.

\subsection{Structural Model}

The hypotheses of this study were tested using the structural model as presented in Figure 3. A covariance was created between the error terms (shown in Figure 3) to gain adequate model fits. We confirmed that the model fits: $\chi 2 / \mathrm{df}=1.910, \mathrm{GFI}=0.83, \mathrm{AGFI}-0.80$, $\mathrm{TLI}=0.90, \mathrm{CFI}=0.91$ and NFI $=0.84$, as per the suggestions of Ding et al. (1995). We then proceeded to explain the results.

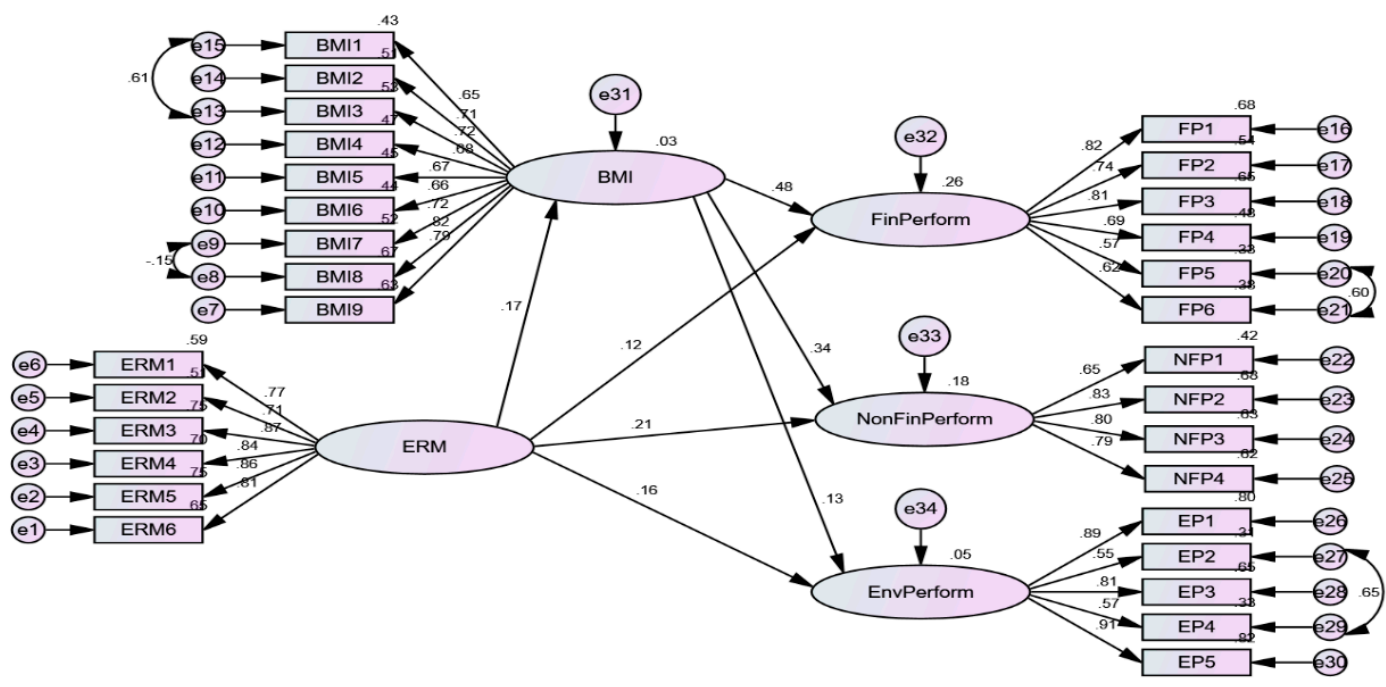

Figure 3. Structural model.

Regarding the direct influence, our results (Table 5) showed that the ERM practices have an insignificant influence on financial performance $(\beta=0.116, p>0.05)$, leading to rejection of H1. However, ERM practices have a significant impact on nonfinancial performance $(\beta=0.213, p<0.05)$ and environmental performance $(\beta=0.165, p>0.05)$, supporting $\mathrm{H} 2$ and $\mathrm{H} 3$ respectively. Both $\mathrm{RMSEA}=0.063$ and $\mathrm{RMR}=0.015$ are acceptable (below 0.09), as recommended by Fan et al. (1999).

ERM has a significant impact on BMI $(\beta=0.166, p<0.05)$, supporting H4. BMI significantly influences financial performance $(\beta=0.476, p<0.05)$ and nonfinancial performance $(\beta=0.366, p<0.05)$ but nonsignificantly influences environmental performance $(\beta=0.129$, $p>0.05)$; thus, H5 and H6 are supported, but H7 is rejected. 
Table 5. Hypotheses testing.

\begin{tabular}{|c|c|c|c|}
\hline Hypothesized Relationship & Direct Impact & Indirect Impact & Total Impact \\
\hline Financial Performance $\leftarrow$ ERM & 0.116 & 0.079 * & $0.195^{* *}$ \\
\hline Nonfinancial Performance $\leftarrow$ ERM & $0.213^{* *}$ & $0.056^{*}$ & $0.269^{* *}$ \\
\hline Environmental Performance $\leftarrow$ ERM & $0.165 *$ & 0.022 & $0.186^{* *}$ \\
\hline $\mathrm{BMI} \leftarrow \mathrm{ERM}$ & $0.166^{*}$ & & $0.166^{*}$ \\
\hline Financial Performance $\leftarrow$ BMI & $0.476^{* *}$ & & $0.476^{* *}$ \\
\hline Nonfinancial Performance $\leftarrow$ BMI & $0.366^{* *}$ & & $0.366^{* *}$ \\
\hline Environmental Performance $\leftarrow$ BMI & 0.129 & & 0.129 \\
\hline
\end{tabular}

Note: ${ }^{* *} p$ value less than $0.01 ;{ }^{*} p$ value less than 0.05

Regarding the mediating role of BMI, our results showed an indirect but significant influence of ERM on financial performance $(\beta=0.079, p<0.05)$ while the direct influence was found to be insignificant, thereby fully supporting the H8. In other words, BMI fully mediates the relationship between ERM and financial performance. ERM practices display an indirect significant impact on nonfinancial performance $(\beta=0.056, p<0.05)$, but the direct influence also remains significant, so $\mathrm{H} 9$ has partially been supported. Finally, this study revealed that the ERM does not have a significant indirect influence on environmental performance (and also the path between BMI and environmental performance is insignificant), confirming that BMI does not play a mediating role between ERM and environmental performance, and thus $\mathrm{H} 10$ has not been supported. R-square showed a $26 \%$ variation in financial performance, $18 \%$ variation in nonfinancial performance and only $5 \%$ variation in environmental performance that can be explained by ERM practices in the presence of BMI. Table 6 shows the summarized results of the hypothesis.

Table 6. Hypotheses remarks.
H1. ERM practices are significantly influencing organizational financial performance.
H2. ERM practices are significantly influence organizational nonfinancial performance.
H3. ERM practices are significantly influence organizational environmental performance.
H4. ERM practices are significantly influence business model innovation in organizations.
H5. BMI significantly influences organizational financial performance.
H6. BMI significantly influences organizational nonfinancial performance.
H7. BMI significantly influences environmental performance.
H8. The association between ERM and financial performance is mediated by BMI.
H9. The association between ERM and nonfinancial performance is mediated by BMI.
H10. The association between ERM and environmental performance is mediated by BMI.

$$
\begin{gathered}
\text { Rejected } \\
\text { Accepted } \\
\text { Accepted } \\
\text { Accepted } \\
\text { Accepted } \\
\text { Accepted } \\
\text { Rejected } \\
\text { Fully accepted } \\
\text { Partially accepted } \\
\text { Rejected }
\end{gathered}
$$

\section{Discussion and Conclusions}

Previous studies in the context of ERM have given more attention to the theoretical and exploratory discussion rather than to empirical evidence (Anwar et al. 2020; Brustbauer 2016; Florio and Leoni 2017). In other words, numerous studies have tested the direct relationship between ERM and firms' performance in both developed and emerging economies (Berry-Stölzle and Xu 2018; Rehman and Anwar 2019; Yang et al. 2018). However, how ERM practices contribute to the financial, nonfinancial and environmental performance of financial institutions has been rarely discussed. In particular, the mediating role of BMI between ERM and firms' performance has mostly remained unanswered. The present study thus considered the mediating role of BMI between ERM practices and an enterprise's environmental, financial and nonfinancial performance in an emerging market. Moreover, this research extends the scope of the RBV theory by examining the influence of ERM on the financial, nonfinancial and environmental performance of financial institutions in an emerging market. Though, the theory has been discussed in countable studies on the relationship between ERM and firms' performance (Rehman and Anwar 2019; Yang et al. 2018). However, this theory has been neglected in terms of ERM, BMI and the financial, nonfinancial and environmental performance of financial institutions. 
This study found an insignificant effect of ERM on financial performance, leading to rejection of H1. Our results do not favor previous studies where a significant positive association between ERM and financial performance was reported (Rehman and Anwar 2019; Soliman and Adam 2017). Our findings scrutinized that the ERM does not directly influence the financial performance of firms in Jordan. Besides, the study examined the influence of ERM nonfinancial performance which supported $\mathrm{H} 2$. Our findings are consistent with Callahan and Soileau (2017) who stated that ERM practices lead to the operational performance of firms. Moreover, Saeidi et al. (2020) also stated that ERM significantly contributes to the nonfinancial performance of financial firms. Similarly, our study also scrutinized a positive and significant association between ERM and environmental performance in the financial sector which favored H3. Our findings are related to Fitriana and Wardhani (2020) who revealed a positive association between ERM and sustainability practices. Similarly, our findings favor Saardchom (2013) who scrutinized a positive association between ERM and sustainability activities in firms.

This study further examined the impact of ERM on BMI and found significant positive results that supported H3. This is in line with Etges et al. (2017) who reported that there is a benefit to implementing risk management practices in the strategic performance model of innovative organizations. However, numerous companies are still choosing to apply any risk management in the BMI process (Taran et al. 2013).

Concerning the influence of BMI on firms' performance, this study found that BMI significantly influences the financial performance and nonfinancial performance, supporting H5 and H6. Our findings support Anwar (2018) who concluded a significant influence of BMI on the financial performance of firms. The results are in agreement with previous studies. For instance, Božič and Dimovski (2019) found that BMI is positively associated with a successful balance between explorative and exploitative innovation activities, which in turn enhances firm performance. Besides, a firm's innovation performance positively influences its business performance (Rangus and Slavec 2017). Moreover, Liem (2018) also revealed a significant association between ERM and banking performance. However, this study revealed that the BMI does not significantly influence the environmental performance in financial firms and thus rejected H7. Our findings were also in contradiction to findings of Schaltegger et al. (2012) who demonstrated that the BMI is an ongoing process that significantly influences sustainability activities in firms.

Regarding the mediating role of BMI, our results showed a significant indirect influence of ERM on financial performance while an insignificant direct influence; thus, H8 was fully supported. In other words, we found that the BMI fully mediates the path between ERM and financial performance. Our findings correspond to Taran et al. (2013) who described that the ERM enables firms in building a good business model that in turn contributes to firms' profitability. However, we found that the ERM practices have both direct and indirect significant impact on nonfinancial performance, which partially supported H9. Our findings are similar to Dellermann et al. (2017) who stated that risk strategies are crucial for digital BMI that in results create customer-directed values for firms. Interestingly, our findings confirmed that the BMI does not play a mediating role between ERM and environmental performance but were partially aligned to Games and Rendi (2019) who indicated that BMI outcomes do not mediate the links between knowledge management, risk-taking, and firms' financial performance.

\subsection{Implications for Practice}

Our research has several implications for senior managers and policy-making groups. First, our findings revealed that the ERM practices do not directly improve the profitability of firms but that BMI affects the path. We found that the ERM practices indirectly contributed to the financial performance of firms through building an effective model. We also found that the ERM practices are equally important for nonfinancial performance and environmental performance and that the BMI partially affects the path between ERM and nonfinancial performance while playing a fully mediating role between ERM and 
financial performance. However, financial firms can build an effective BMI by adopting ERM practices. Our results suggested that promoting ERM practices directly or indirectly contributes to financial firms' performance. Moreover, in the current era of globalization, managers and responsible executives of financial firms should look for a unique BMI to compete in the market and gain superior performance. However, BMI is not automatically built but requires capabilities and resources (Anwar and Shah 2020).

Based upon our findings, it is recommended that the financial institutions shall apply ERM because it is a significant predictor that can facilitate them in producing a useful BMI. Alternatively, BMI constructs the financial and nonfinancial performance of the financial firms. More specifically, if the banking sector needs to spur their financial and nonfinancial performance, they should rely on their BMI. However, in terms of environmental performance, financial firms should investigate other parameters to understand why BMI is not the best source to improve environmental performance.

To summarize, this research has two key implications: first, financial firms need to focus on ERM practices because these practices facilitate their BMI so that it results in high performance; and second, financial firms and banks should investigate why BMI does not influence their environmental outcomes and how it can be improved to spur their social and environmental activities. Based upon our findings, it is recommended that the policymakers and the Jordanian government should initiate programs for improving ERM practices in financial institutions and banks. They can facilitate businesses in terms of financial education, ERM practices, financial prediction, risk mitigation and future forecasting to reduce potential threats. Our research also recommends to the financial institutions to implement a formal framework for ERM to establish an effective BMI that helps in improving financial and nonfinancial performance. Moreover, top managers and responsible executives of the firms are advised to investigate the practices deeply to spur environmental performance. Additionally, these recommendations can be applied in other countries, including developed and emerging economies, to check the validity of the results.

To conclude, this study examined the impact of ERM practices on Jordanian financial sector performance by exploring the mediating role of BMI between ERM and financial firms' performance. A structured questionnaire was used to collect data from 228 Jordanian financial sector firms. The research hypotheses were tested through SEM and AMOS. The results indicate that ERM practices have a significant influence on BMI and financial firms performance. BMI significantly contributes to financial and nonfinancial performance, while it displays nonsignificant results for environmental performance. BMI fully mediates the relationship between ERM practices and financial performance, partially mediates the path between ERM practices and nonfinancial performance and shows no mediating role between ERM practices and environmental performance.

\subsection{Limitations and Future Research Directions}

Despite having important policy implications, the present study has several limitations that can be mitigated in future research work. The first limitation of this study was found to be related to the sampling frame and population. In instant study, only Jordanian firms were surveyed, which may not be an effective representative of the financial firms working in emerging and European markets. Gathering evidence from other markets can strengthen the insights and lead to broader implications. Second, we applied cross-sectional data, which has been criticized for common method variance. To reduce the threat, we suggest that a few managers and executives may be interviewed to explore comprehensive information. Moreover, if possible, achieved data will provide trustable insights in future studies; therefore, researchers are advised to use reported data to test the model. The third limitation of this research was linked to the conceptual framework. We tested the role of ERM practices in banking and financial firms' performance (financial, nonfinancial and environmental) with a mediating role of BMI. The existing framework is novel and makes a clear contribution. However, other relevant moderators and mediators can be 
considered in the model to articulate the results in a better way. For instance, da Silva Etges and Cortimiglia (2019) claimed that there is a relationship between risk management and innovation. However, the question of what types of innovation-products, processes, organizations and marketing-are related to ERM practices are neglected, thereby indicating a path for researchers to explore. Fourth, we did not control the demographic factors of managers, such as qualification, age, experience and income, nor did we control the nature of industry. These can be controlled in future studies to attenuate the presence of spurious results. Moreover, it is worth noting that ERM practices are significantly related to the strategic planning of enterprises (Sax and Andersen 2019). Therefore, strategic resources and planning can be considered in future studies as intervening factors in the model. Additionally, evidence from emerging and European financial firms can further inform policy.

Author Contributions: M.A.-N.: original draft, conceptualization, A.A.-O.: Data curation and analysis, S.S.A.: Methodology and discussion revision, H.A.: Literature and revision. All authors have read and agreed to the published version of the manuscript.

Funding: This research has not received funding.

Institutional Review Board Statement: The Hashemite University approved the research.

Informed Consent Statement: Consent was not concerned in this study.

Data Availability Statement: The data can be obtained on request from the corresponding author.

Conflicts of Interest: The authors have no conflict of interest.

\section{Appendix A}

Enterprise Risk Management

1. Our firm has a policy for handling major risks that could affect the firm's ability to reach its strategic objectives

2. We have standard procedures in place for identifying major risks and opportunities

3. Risks and opportunities are analyzed as a basis for determining how they should be managed

4. We have standard procedures in place for launching risk-reducing measures

5. We regularly prepare risk reports for the top management and the board of directors

6. We have standard procedures in place for monitoring the developments in major risks and the risk-reducing measures launched Business Model Innovation

1. Our business model offers new combinations of products, services and information

2. Our business model attracts a lot of new customers

3. Our business model attracts a lot of new suppliers and partners

4. Our business model bonds participants together in novel ways

5. Our business model links participants to transactions in novel ways

6. We frequently introduce new ideas and innovations into our business model

7. We frequently introduce new operational processes, routines and norms into our BM

8. We are pioneers of the business model

9. Overall, our business model is novel 
Financial Performance

1. Return on equity

2. Return on sales

3. Return on investment

4. Return on assets

5. Sales growth

6. Net profitability

Nonfinancial Performance

1. Customer satisfaction

2. Employees satisfaction

3. Product/service quality

4. Employee loyalty

Environmental Performance

1. Designs products and packaging to be reused, repaired or recycled

2. Exceeds voluntarily environmental regulations

3. Invest in saving energy

4. Adopts measures to design ecological products or services

5. Performs environmental audits periodically

\section{References}

Adam, Mukhtar, Alaa M. Soliman, and Nehal Mahtab. 2021. Measuring Enterprise Risk Management implementation: A multifaceted approach for the banking sector. The Quarterly Review of Economics and Finance. [CrossRef]

Adedayo, Erin Olayinka, Eriabie Sylvester, and Omoike Osereme Amiolemen. 2019. Does enterprise risk management impact accounting quality? Evidence from the Nigerian financial institutions. Investment Management E Financial Innovations 16: 16.

Altanashat, Mohammad, Maged Al Dubai, and Sadun Alhety. 2019. The impact of enterprise risk management on institutional performance in Jordanian public shareholding companies. Journal of Business E Retail Management Research 13: 256-69.

Amankwah-Amoah, Joseph, Albert Danso, and Samuel Adomako. 2019. Entrepreneurial orientation, environmental sustainability and new venture performance: Does stakeholder integration matter? Business Strategy and the Environment 28: 79-87. [CrossRef]

Anwar, Muhammad. 2018. Business model innovation and SMEs performance-Does competitive advantage mediate? International Journal of Innovation Management 22: 1850057. [CrossRef]

Anwar, Muhammad, and Syed Zulfiqar Ali Shah. 2020. Managerial networking and business model innovation: Empirical study of new ventures in an emerging economy. Journal of Small Business E Entrepreneurship 32: 265-86.

Anwar, Muhammad, and Syed Zulfiqar Ali Shah. 2020. Entrepreneurial orientation and generic competitive strategies for emerging SMEs: Financial and nonfinancial performance perspective. Journal of Public Affairs 21: e2125. [CrossRef]

Anwar, Muhammad, Syed Zulfiqar Ali Shah, Sher Zaman Khan, and Muhammad Sualeh Khattak. 2019. Manager's personality and business model innovation. International Journal of Innovation Management 23: 1950061. [CrossRef]

Anwar, Muhammad, Sher Zaman Khan, and Syed Zulfiqar Ali Shah. 2020. A study of the relationship between innovation and performance among NPOs in Pakistan. Journal of Social Service Research 46: 26-40. [CrossRef]

Asemokha, Agnes, Jackson Musona, Lasse Torkkeli, and Sami Saarenketo. 2019. Business model innovation and entrepreneurial orientation relationships in SMEs: Implications for international performance. Journal of International Entrepreneurship 17: 425-53. [CrossRef]

Bamfo, Bylon Abeeku, and Jerry Jay Kraa. 2019. Market orientation and performance of small and medium enterprises in Ghana: The mediating role of innovation. Cogent Business \& Management 6: 1605703.

Barney, J. 1991. Firm resources and sustained competitive advantage. Journal of Management 17: 99-120. [CrossRef]

Berry-Stölzle, Thomas R., and Jianren Xu. 2018. Enterprise risk management and the cost of capital. Journal of Risk and Insurance 85: 159-201. [CrossRef]

Božič, Katerina, and Vlado Dimovski. 2019. Business intelligence and analytics use, innovation ambidexterity, and firm performance: A dynamic capabilities perspective. The Journal of Strategic Information Systems 28: 101578. [CrossRef] 
Brustbauer, Johannes. 2016. Enterprise risk management in SMEs: Towards a structural model. International Small Business Journal 34: 70-85. [CrossRef]

Callahan, Carolyn, and Jared Soileau. 2017. Does enterprise risk management enhance operating performance? Advances in accounting 37: 122-39. [CrossRef]

Casadesus-Masanell, Ramon, and Feng Zhu. 2013. Business model innovation and competitive imitation: The case of sponsor-based business models. Strategic Management Journal 34: 464-82. [CrossRef]

Chege, Samwel Macharia, and Daoping Wang. 2020. The influence of technology innovation on SME performance through environmental sustainability practices in Kenya. Technology in Society 60: 101210. [CrossRef]

Chen, Yu-Lun, Yi-Wei Chuang, Hong-Gia Huang, and Jhuan-Yu Shih. 2020. The value of implementing enterprise risk management: Evidence from Taiwan's financial industry. The North American Journal of Economics and Finance 54: 100926. [CrossRef]

COSO. 2004. Enterprise Risk Management-Integrated Framework. New York: Committee of Sponsoring Organizations of the Treadway Commission, vol. 2.

da Silva Etges, Ana Paula Beck, and Marcelo Nogueira Cortimiglia. 2019. A systematic review of risk management in innovationoriented firms. Journal of Risk Research 22: 364-81. [CrossRef]

Dellermann, Dominik, Alexander Fliaster, and Michael Kolloch. 2017. Innovation risk in digital business models: The German energy sector. Journal of Business Strategy 38: 35-43. [CrossRef]

Demartini, Maria Chiara, and Valentina Beretta. 2020. Intellectual capital and SMEs' performance: A structured literature review. Journal of Small Business Management 58: 288-332. [CrossRef]

Dey, Ripon Kumar, Syed Zabid Hossain, and Zabihollah Rezaee. 2018. Financial Risk Disclosure and Financial Attributes among Publicly Traded Manufacturing Companies: Evidence from Bangladesh. Journal of Risk and Financial Management 11: 50. [CrossRef]

Di Gravio, Giulio, Francesco Costantino, and Massimo Tronci. 2013. Enterprise Risk Management to Drive Operations Performances. Operations Management 163.

Ding, Lin, Wayne F. Velicer, and Lisa L. Harlow. 1995. Effects of estimation methods, number of indicators per factor, and improper solutions on structural equation modeling fit indices. Structural Equation Modeling: A Multidisciplinary Journal 2: 119-43. [CrossRef]

Etges, Ana Paula Beck da Silva, Joana Siqueira de Souza, and Francisco José Kliemann Neto. 2017. Risk management for companies focused on innovation processes. Production 27. [CrossRef]

Fan, Xitao, Bruce Thompson, and Lin Wang. 1999. Effects of sample size, estimation methods, and model specification on structural equation modeling fit indexes. Structural Equation Modeling: A Multidisciplinary Journal 6: 56-83. [CrossRef]

Fitriana, S., and R. Wardhani. 2020. The effect of enterprise risk management and sustainability reporting quality on performance: Evidence from Southeast Asia countries. International Journal of Economic Policy in Emerging Economies 13: 344-55. [CrossRef]

Florio, Cristina, and Giulia Leoni. 2017. Enterprise risk management and firm performance: The Italian case. The British Accounting Review 49: 56-74. [CrossRef]

Foerstl, Kai, Carsten Reuter, Evi Hartmann, and Constantin Blome. 2010. Managing supplier sustainability risks in a dynamically changing environment-Sustainable supplier management in the chemical industry. Journal of Purchasing and Supply Management 16: 118-30. [CrossRef]

Foss, Nicolai J., and Tina Saebi. 2017. Fifteen years of research on business model innovation: How far have we come, and where should we go? Journal of Management 43: 200-27. [CrossRef]

Futterer, Fabian, Jochen Schmidt, and Sven Heidenreich. 2018. Effectuation or causation as the key to corporate venture success? Investigating effects of entrepreneurial behaviors on business model innovation and venture performance. Long Range Planning 51: 64-81. [CrossRef]

Games, Donard, and Ranggi Putri Rendi. 2019. The effects of knowledge management and risk taking on SME financial performance in creative industries in an emerging market: The mediating effect of innovation outcomes. Journal of Global Entrepreneurship Research 9: 44. [CrossRef]

Garver, Michael S., and John T. Mentzer. 1999. Logistics research methods: Employing structural equation modeling to test for construct validity. Journal of Business Logistics 20: 33.

Geissdoerfer, Martin, Doroteya Vladimirova, and Steve Evans. 2018. Sustainable business model innovation: A review. Journal of Cleaner Production 198: 401-16. [CrossRef]

George, Darren. 2011. SPSS for Windows Step by Step: A Simple Study Guide and Reference, 17.0 Update, 10/e. Delhi: Pearson Education India.

Guo, Hai, Jintong Tang, Zhongfeng Su, and Jerome A. Katz. 2017. Opportunity recognition and SME performance: The mediating effect of business model innovation. RED Management 47: 431-42.

Guo, Hai, Jing Zhao, and Jintong Tang. 2013. The role of top managers' human and social capital in business model innovation. Chinese Management Studies 7: 447-69. [CrossRef]

Hair, Joe F., Jr., Lucy M. Matthews, Ryan L. Matthews, and Marko Sarstedt. 2017. PLS-SEM or CB-SEM: Updated guidelines on which method to use. International Journal of Multivariate Data Analysis 1: 107-23. [CrossRef]

Hamelink, Martijn, and Raymond Opdenakker. 2019. How business model innovation affects firm performance in the energy storage market. Renewable Energy 131: 120-27. [CrossRef]

Hendriks, Christoffel. 2013. Integrated Financial Management Information Systems: Guidelines for effective implementation by the public sector of South Africa. South African Journal of Information Management 15: 1-9. [CrossRef] 
Hock-Doepgen, Marianne, Thomas Clauss, Sascha Kraus, and Cheng-Feng Cheng. 2020. Knowledge management capabilities and organizational risk-taking for business model innovation in SMEs. Journal of Business Research. [CrossRef]

Hopper, Greg. 2019. The enterprise risk management function in financial institutions. Journal of Risk Management in Financial Institutions 12: 328-41.

Ilyas, Sana, Zhineng Hu, and Kunakorn Wiwattanakornwong. 2020. Unleashing the role of top management and government support in green supply chain management and sustainable development goals. Environmental Science and Pollution Research 27: 8210-23. [CrossRef]

Jonek-Kowalska, Izabela. 2019. Efficiency of Enterprise Risk Management (ERM) systems. Comparative analysis in the fuel sector and energy sector on the basis of Central-European companies listed on the Warsaw Stock Exchange. Resources Policy 62: 405-15. [CrossRef]

Kalvet, Tarmo, and Veiko Lember. 2010. Risk management in public procurement for innovation: The case of Nordic-Baltic Sea cities. Innovation-the European Journal of Social Science Research 23: 241-62. [CrossRef]

Karimi, Jahangir, and Zhiping Walter. 2016. Corporate entrepreneurship, disruptive business model innovation adoption, and its performance: The case of the newspaper industry. Long Range Planning 49: 342-60. [CrossRef]

Shad, Muhammad Kashif, and Fong-Woon Lai. 2019. Enterprise Risk Management Implementation and Firm Performance: Evidence from the Malaysian Oil and Gas Industry. International Journal of Business and Management 14: 47. [CrossRef]

Khattak, Muhammad Sualeh. 2020. Does access to domestic finance and international finance contribute to sustainable development goals? Implications for policymakers. Journal of Public Affairs 20: 20-24. [CrossRef]

Khresiat, Ola. 2019. Impact of Investment Decisions on the Profits of Jordanian Insurance Companies Listed on the Amman Stock Exchange. Academy of Accounting and Financial Studies Journal 23: 1-12.

Kmieciak, Roman, and Anna Michna. 2018. Knowledge management orientation, innovativeness, and competitive intensity: Evidence from Polish SMEs. Knowledge Management Research E Practice 16: 559-72.

Ivanyos, János, and Éva Sándor-Kriszt. 2016. Risk Management Measurement and Evaluation Methods Based on Performance Indicators. Public Finance Quarterly 61: 265-81.

Liem, Christina. 2018. Enterprise Risk Management in Banking Industry. Firm Journal of Management Studies 3: 1-15. [CrossRef]

Lin, Woon Leong, Nick Yip, Jo Ann Ho, and Murali Sambasivan. 2020. The adoption of technological innovations in a B2B context and its impact on firm performance: An ethical leadership perspective. Industrial Marketing Management 89: 61-71. [CrossRef]

Lin, Yijia, Min-Ming Wen, and Jifeng Yu. 2012. Enterprise risk management: Strategic antecedents, risk integration, and performance. North American Actuarial Journal 16: 1-28. [CrossRef]

Lobo, Gerald J., Wei Z. Siqueira, Kinsun Tam, and Jian Zhou. 2019. Does SEC FRR No. 48 disclosure communicate risk management effectiveness? Journal of Accounting and Public Policy 38: 106696. [CrossRef]

Malik, Muhammad Farhan, Mahbub Zaman, and Sherrena Buckby. 2020. Enterprise risk management and firm performance: Role of the risk committee. Journal of Contemporary Accounting \& Economics 16: 100178.

Markides, Constantinos. 2006. Disruptive innovation: In the need for better theory. Journal of Product Innovation Management 23: 19-25. [CrossRef]

Markides, Constantinos. 2013. Business model innovation: What can the ambidexterity literature teach us? The Academy of Management Perspectives 27: 313-23. [CrossRef]

Martinez-Conesa, Isabel, Pedro Soto-Acosta, and Mercedes Palacios-Manzano. 2017. Corporate social responsibility and its effect on innovation and firm performance: An empirical research in SMEs. Journal of Cleaner Production 142: 2374-83. [CrossRef]

Maruhun, Enny Nurdin Sutan, Wan Razazila Wan Abdullah, Ruhaya Atan, and Sharifah Norzehan Syed Yusuf. 2018. The effects of corporate governance on enterprise risk management: Evidence from Malaysian Shariah-compliant firms. International Journal of Academic Research in Business and Social Sciences 8: 865-77. [CrossRef]

Memon, Aasma, Zhang Yong An, and Muhammad Qasim Memon. 2020. Does financial availability sustain financial, innovative, and environmental performance? Relation via opportunity recognition. Corporate Social Responsibility and Environmental Management 27: 562-75. [CrossRef]

Morris, Michael H., Galina Shirokova, and Alexander Shatalov. 2013. The business model and firm performance: The case of Russian food service ventures. Journal of Small Business Management 51: 46-65. [CrossRef]

Mustafa, Fairouz Mohammed, and Munther Barakat Al-Nimer. 2018. The association between enterprise risk management and corporate governance quality: The mediating role of internal audit performance. Journal of Advanced Research in Law and Economics 9: 1387-401. [CrossRef]

Najmaei, Arash. 2016. Revisiting the modularity-performance nexus: Business model innovation as a missing mechanism. International Journal of Innovation Management 20: 1650065. [CrossRef]

Olayinka, Erin, Eriki Emoarehi, Arumona Jonah, and Jacob Ame. 2017. Enterprise Risk Management and Financial Performance: Evidence from Emerging Market. Journal of Management, Accounting and Economics 4: 937-52.

Panić, Marija, Milica Veličković, Danijela Voza, Živan Živković, and Zuzana Virglerová. 2019. The impact of enterprise risk management on the performance of companies in transition countries: Serbia case study. Journal of Operational Risk 14: 105-32.

Pierce, Elizabeth M., and James Goldstein. 2018. ERM and strategic planning: A change in paradigm. International Journal of Disclosure and Governance 15: 51-59. [CrossRef] 
Podsakoff, Philip M., and Dennis W. Organ. 1986. Self-reports in organizational research: Problems and prospects. Journal of management 12: 531-44. [CrossRef]

Rajapathirana, RP Jayani, and Yan Hui. 2018. Relationship between innovation capability, innovation type, and firm performance. Journal of Innovation \& Knowledge 3: 44-55.

Rangus, Kaja, and Alenka Slavec. 2017. The interplay of decentralization, employee involvement and absorptive capacity on firms' innovation and business performance. Technological Forecasting and Social Change 120: 195-203. [CrossRef]

Rasid, Siti Zaleha Abdul, Nargess Golshan, Mozhdeh Mokhber, Gi-Gi Tan, and Nor Aiza Mohd-Zamil. 2017. Enterprise risk management, performance measurement systems and organizational performance in Malaysian Public Listed Firms. International Journal of Business and Society 18: 2.

Rasid, Siti Zaleha Abdul, Che Ruhana Isa, and Wan Khairuzzaman Wan Ismail Ismail. 2014. Management accounting systems, enterprise risk management and organizational performance in financial institutions. Asian Review of Accounting 22: 128-44. [CrossRef]

Rehman, Amin Ur, and Muhammad Anwar. 2019. Mediating role of enterprise risk management practices between business strategy and SME performance. Small Enterprise Research 26: 207-27. [CrossRef]

Rodríguez, Alicia, and María Jesús Nieto. 2016. Does R\&D offshoring lead to SME growth? D ifferent governance modes and the mediating role of innovation. Strategic Management Journal 37: 1734-53.

Rodríguez, Rocío, Francisco-Jose Molina-Castillo, and Göran Svensson Svensson. 2020. The mediating role of organizational complexity between enterprise resource planning and business model innovation. Industrial Marketing Management 84: 328-41. [CrossRef]

Roxas, Banjo, and Doren Chadee. 2016. Knowledge management view of environmental sustainability in manufacturing SMEs in the Philippines. Knowledge Management Research E Practice 14: 514-24.

Ruiz-Jiménez, Jenny María, and María del Mar Fuentes-Fuentes. 2013. Knowledge combination, innovation, organizational performance in technology firms. Industrial Management $\mathcal{E}$ Data Systems 113: 523-40.

Saardchom, Narumon. 2013. Enterprise risk management under sustainability platform. Journal of Business and Economics 4: 32-41.

Saeidi, Parvaneh, Sayyedeh Parisa Saeidi, Leonardo Gutierrez, Dalia Streimikiene, Melfi Alrasheedi, Sayedeh Parastoo Saeidi, and Abbas Mardani. 2020. The influence of enterprise risk management on firm performance with the moderating effect of intellectual capital dimensions. Economic Research-Ekonomska Istraživanja, 1-30. [CrossRef]

Saeidi, Parvaneh, Sayyedeh Parisa Saeidi, Saudah Sofian, Sayedeh Parastoo Saeidi, Mehrbakhsh Nilashi, and Abbas Mardani. 2019. The impact of enterprise risk management on competitive advantage by moderating role of information technology. Computer Standards \& Interfaces 63: 67-82.

Sax, Johanna, and Torben Juul Andersen. 2019. Making risk management strategic: Integrating enterprise risk management with strategic planning. European Management Review 16: 719-40. [CrossRef]

Schaltegger, Stefan, Florian Lüdeke-Freund, and Erik G. Hansen Hansen. 2012. Business cases for sustainability: The role of business model innovation for corporate sustainability. International Journal of Innovation and Sustainable Development 6: 95-119. [CrossRef]

Shad, Muhammad Kashif, Fong-Woon Lai, Chuah Lai Fatt, Jiř́ Jaromír Klemeš, and Awais Bokhari. 2019. Integrating sustainability reporting into enterprise risk management and its relationship with business performance: A conceptual framework. Journal of Cleaner Production 208: 415-25. [CrossRef]

Singh, Rajesh Kr, Sunil Luthra, Sachin Kumar Mangla, and Surbhi Uniyal. 2019. Applications of information and communication technology for sustainable growth of SMEs in India food industry. Resources, Conservation and Recycling 147: 10-18. [CrossRef]

Soliman, Alaa, and Mukhtar Adam. 2017. Enterprise risk management and firm performance: An integrated model for the banking sector. Banks and Bank Systems 12: 116-23. [CrossRef]

Soltanizadeh, Sara, Siti Zaleha Abdul Rasid, Nargess Mottaghi Golshan, and Wan Khairuzzaman Wan Ismail. 2016. Business strategy, enterprise risk management and organizational performance. Management Research Review 39: 1016-33. [CrossRef]

Spieth, Patrick, Dirk Schneckenberg, and Joan E. Ricart. 2014. Business model innovation-state of the art and future challenges for the field. REd Management 44: 237-47.

Taran, Yariv, Harry Boer, and Peter Lindgren. 2013. Incorporating enterprise risk management in the business model innovation process. Journal of Business Models 1: 1.

Taran, Yariv, René Chester Goduscheit, and Harry Boer. 2015. Managing business model innovation risks-lessons for theory and practice. Present at the 16th International CINet Conference on Pursuing Innovation Leadership, Stockholm, Sweden, September 13-15; pp. 919-29.

Velu, Chander. 2015. Business model innovation and third-party alliance on the survival of new firms. Technovation 35: 1-11. [CrossRef]

Velu, Chander, and Philip Stiles. 2013. Managing decision-making and cannibalization for parallel business models. Long Range Planning 46: 443-58. [CrossRef]

Whitman, Andrew. 2015. Is ERM legally required? Yes for financial and governmental institutions, no for private enterprises. Risk Management and Insurance Review 18: 161-97. [CrossRef]

Wijethilake, Chaminda, and Tek Lama. 2019. Sustainability core values and sustainability risk management: Moderating effects of top management commitment and stakeholder pressure. Business Strategy and the Environment 28: 143-54. [CrossRef]

$\mathrm{Wu}$, Jie, and Zefu Wu. 2014. Integrated risk management and product innovation in China: The moderating role of board of directors. Technovation 34: 466-76. [CrossRef] 
Yang, Songling, Muhammad Ishtiaq, and Muhammad Anwar. 2018. Enterprise risk management practices and firm performance, the mediating role of competitive advantage and the moderating role of financial literacy. Journal of Risk and Financial Management 11: 35.

Zott, Christoph, and Raphael Amit. 2008. The fit between product market strategy and business model: Implications for firm performance. Strategic Management Journal 29: 1-26. [CrossRef] 